Article

\title{
Increasing Odontoblast-like Differentiation from Dental Pulp Stem Cells through Increase of $\beta$-Catenin/p-GSK-3 $\beta$ Expression by Low-Frequency Electromagnetic Field
}

\author{
Han-Moi Lim, Myeong-Hyun Nam, Yu-Mi Kim and Young-Kwon Seo *(D)
}

check for

updates

Citation: Lim, H.-M.; Nam, M.-H.; Kim, Y.-M.; Seo, Y.-K. Increasing Odontoblast-like Differentiation from Dental Pulp Stem Cells through Increase of $\beta$-Catenin $/ \mathrm{p}$-GSK-3 $\beta$ Expression by Low-Frequency Electromagnetic Field. Biomedicines 2021, 9, 1049. https://doi.org/ 10.3390/biomedicines 9081049

Academic Editors: Federico Mussano and Davide Cavagnetto

Received: 7 July 2021

Accepted: 17 August 2021

Published: 19 August 2021

Publisher's Note: MDPI stays neutral with regard to jurisdictional claims in published maps and institutional affiliations.

Copyright: (c) 2021 by the authors. Licensee MDPI, Basel, Switzerland This article is an open access article distributed under the terms and conditions of the Creative Commons Attribution (CC BY) license (https:// creativecommons.org/licenses/by/ $4.0 /$ )
Department of Medical Biotechnology, Dongguk University, Goyang-si 10326, Korea; gksah1321@gmail.com (H.-M.L.); iis05047@naver.com (M.-H.N.); kjmtik@nate.com (Y.-M.K.)

* Correspondence: bioseo@dongguk.edu; Tel.: +82-31-961-5154; Fax: +82-31-961-5621

\begin{abstract}
Odontoblasts produce proteins that form the dentinal extracellular matrix, which can protect the dental pulp from external stimuli and is required for tooth regeneration. This study showed that a pulsed electromagnetic field (PEMF) can regulate cell metabolism and induce cell differentiation. This study determined the frequency of PEMF that is effective for odontoblast differentiation. Human dental pulp stem cells (hDPSCs) were cultured in odontoblast differentiation medium containing dexamethasone, BMP2, TGF- $\beta 1$, and FGF-2, and then exposed to $10 \mathrm{mT}$ intensity of PEMF at 40,60, 70, and $150 \mathrm{~Hz}$ for $15 \mathrm{~min}$ / day. The MTT assay, LDH assay, flow cytometry, protein and gene expression, and immunofluorescence were performed to check if hDPSCs differentiated into odontoblast-like cells. The hDPSCs showed frequency-dependent differences in protein and gene expression. The mesenchymal stem cell markers were reduced to a greater extent at $60 \mathrm{and} 70 \mathrm{~Hz}$ than at other frequencies, and odontoblast-related markers, particularly $\beta$-catenin, $\mathrm{p}$-GSK-3 $\beta$, and p-p38, were increased at 60 and $70 \mathrm{~Hz}$. Exposure to $10 \mathrm{mT}$ intensity of PEMF at $70 \mathrm{~Hz}$ influenced the differentiation of hDPSCs considerably. Taken together, PEMF treatment can promote differentiation of hDPSCs into odontoblast-like cells by increasing p-GSK-3 $\beta$ and $\beta$-catenin expression.
\end{abstract}

Keywords: human dental pulp stem cells; odontoblasts; pulsed electromagnetic field; odontogenesis; GSK-3 $\beta ; \beta$-catenin

\section{Introduction}

Human dental pulp stem cells (hDPSCs) are located in teeth [1,2], where they can differentiate into specific cell types, similar to other mesenchymal stem cells (MSCs) [3-6]. hDPSCs can also differentiate into cells called odontoblasts that form a single-cell layer along the dental pulp-dentin border [7]. Odontoblasts secrete the extracellular matrix components of dentin which act as barriers to dental pulp protection from external stimuli. These specialized cells produce proteins that form the dental pulp extracellular matrix, which is comprised of dentin matrix acidic phosphoprotein 1 (DMP-1) and dentin sialophosphoprotein (DSPP) [8-11]. DMP-1 and DSPP are considered typical markers of odontogenesis [12,13] and reportedly play a role in mineralization [14,15]. Additionally, DMP-1 plays a key role in odontogenesis, and its expression is essential for late dentinogenesis development [8].

Substantial research has been conducted on odontoblast differentiation. A comparative study revealed the differentiation of DPSCs, bone marrow-derived mesenchymal stem cells (BM-MSCs), and adipose-derived MSCs into odontoblast-like cells using a differentiation medium [16]. Most researchers performed studies using growth factors and cytokines. Kidwai et al. [17] and Ozeki et al. [18] differentiated embryonic stem cells into odontoblastlike cells using bone morphogenetic protein-4. Jiang et al. induced the differentiation of cranial neural crest cells into odontoblast-like cells by fibroblast growth factor 8 and adult extracellular matrix proteins [17]. In another study, BM-MSCs and amniotic MSCs 
were differentiated into odontoblast-like cells using a porous scaffold and mechanical stimulation [19]. Those authors applied $19.6 \mathrm{kPa}$ of mechanical compression onto the microporous scaffold for nine hours, which increased the expression of odontoblast-related markers [18]. Likewise, in a study by Liao et al., mechanical tension induced odontogeniclike differentiation of hDPSCs through the STAT3 signaling pathway by downregulating sclerostin expression and accelerated senescence of dental pulp cells [20]. Another study promoted odontogenic-like differentiation of BM-MSCs by co-culturing with oral epithelial cells [21]. The differentiation-induced cells showed increased expression of DMP-1 and DSPP, and when transplanted in a model rat with dentin defect, a dentin-like structure was regenerated [19].

Electromagnetic fields (EMFs) affect cell activity, proliferation, and differentiation by affecting cell membranes or intracellular proteins, such as ion channels [21,22]. The cell differentiation effects of EMFs have been widely reported, including the differentiation of MSCs into nerve-, bone-, and joint-related specialized cells [23-25]. Since Basset et al. first introduced EMFs for bone fracture therapy in 1974 [26], other investigators have used EMFs to increase osteogenic activity and differentiation of bone cells [27-29].

Martino et al. revealed a dramatic increase in mineral nodule formation and alkaline phosphatase (ALP) activity of SaOS-2 cells exposed to $0.9 \mathrm{mT}$ and $15 \mathrm{~Hz}$ of EMF for four hours per day [29]. Jazayeri et al. showed that $15 \mathrm{~Hz}$ and $0.2 \mathrm{mT}$ of EMF exposure for six hours per day induced differentiation of rat MSCs to osteoblast-like cells [30]. Another researcher exposed ( $24 \mathrm{~h} /$ day) alveolar bone-derived MSCs to various frequencies $(10-100 \mathrm{~Hz})$ of EMF $(0.6 \mathrm{mT})$ and noticed a high increase in the proliferation, mineralization, ALP, vinculin, vimentin, and calmodulin expression at $50 \mathrm{~Hz}$ [31]. By contrast, $15 \mathrm{~Hz}$ and low intensity $(0.1 \mathrm{mT})$ of EMF exposure for eight hours per day did not affect the extracellular matrix synthesis of mouse osteoblasts, decreased ALP activity and the receptor activator of nuclear factor-kappa B ligand (RANKL) expression, but increased osteoblastic proliferation [32].

Analysis of the related research suggests that the effect of EMF can be regulated by controlling the intensity, frequency, and exposure time, affecting the proliferation and differentiation of various cells. Thus, we hypothesized that odontoblastic differentiation would be affected by exposure to high-intensity $(10 \mathrm{mT})$ short-time (15 min/day) PEMF. We verified the effects of PEMF by analyzing the gene and protein expression levels of hDPSCs exposed to PEMF at different frequencies to find changes indicative of abilities of DPSC to differentiate into odontoblast-like cells.

\section{Materials and Methods}

\subsection{Preparation and Culture of hDPSCs}

hDPSCs were purchased from Lonza (PT-5025; Basel, Switzerland). The cells were cultured in a growth medium; a Dulbecco's modified Eagle's medium (DMEM) with low glucose (Welgene, Daejeon, Korea) supplemented with 10\% D-glucose (Welgene), fetal bovine serum (FBS; BioWhittaker ${ }^{\mathrm{TM}}$, Cambrex Biosciences, Walkerville, MD, USA), and penicillin-streptomycin (Welgene). The final concentration of medium constituents was $0.09 \%$ D-glucose, 10\% FBS, and 1\% penicillin-streptomycin. The cells were incubated at $37^{\circ} \mathrm{C}$ in a humidified atmosphere with $5 \% \mathrm{CO}_{2}$.

\subsection{Odontoblast-Like Differentiation of hDPSCs}

To induce odontoblast-like differentiation, hDPSCs were treated with odontoblastic differentiation medium; growth medium with $10 \mathrm{nM}$ dexamethasone, $50 \mathrm{ng} / \mathrm{mL} \mathrm{BMP2,}$ $20 \mathrm{ng} / \mathrm{mL}$ transforming growth factor- $\beta 1$, and $5 \mathrm{ng} / \mathrm{mL}$ fibroblast growth factor- 2 (all from Sigma-Aldrich, St. Louis, MO, USA), for 3-10 days with or without PEMF [33]. Control cultures were placed elsewhere to avoid exposure to PEMF and were incubated with the same medium as described for the experimental cultures. 


\subsection{PEMF}

We used Helmholtz coils to generate PEMF (Figure 1). The stimulus form was a pulse, and the stimulation intensity was $10 \mathrm{mT}$. The PEMF frequencies were 40, 60, 70, and $150 \mathrm{~Hz}$. The PEMF device was placed in an incubator at $37^{\circ} \mathrm{C}$ with $5 \% \mathrm{CO}_{2}$. The cells were exposed to PEMF for $15 \mathrm{~min} /$ day for 3 days.
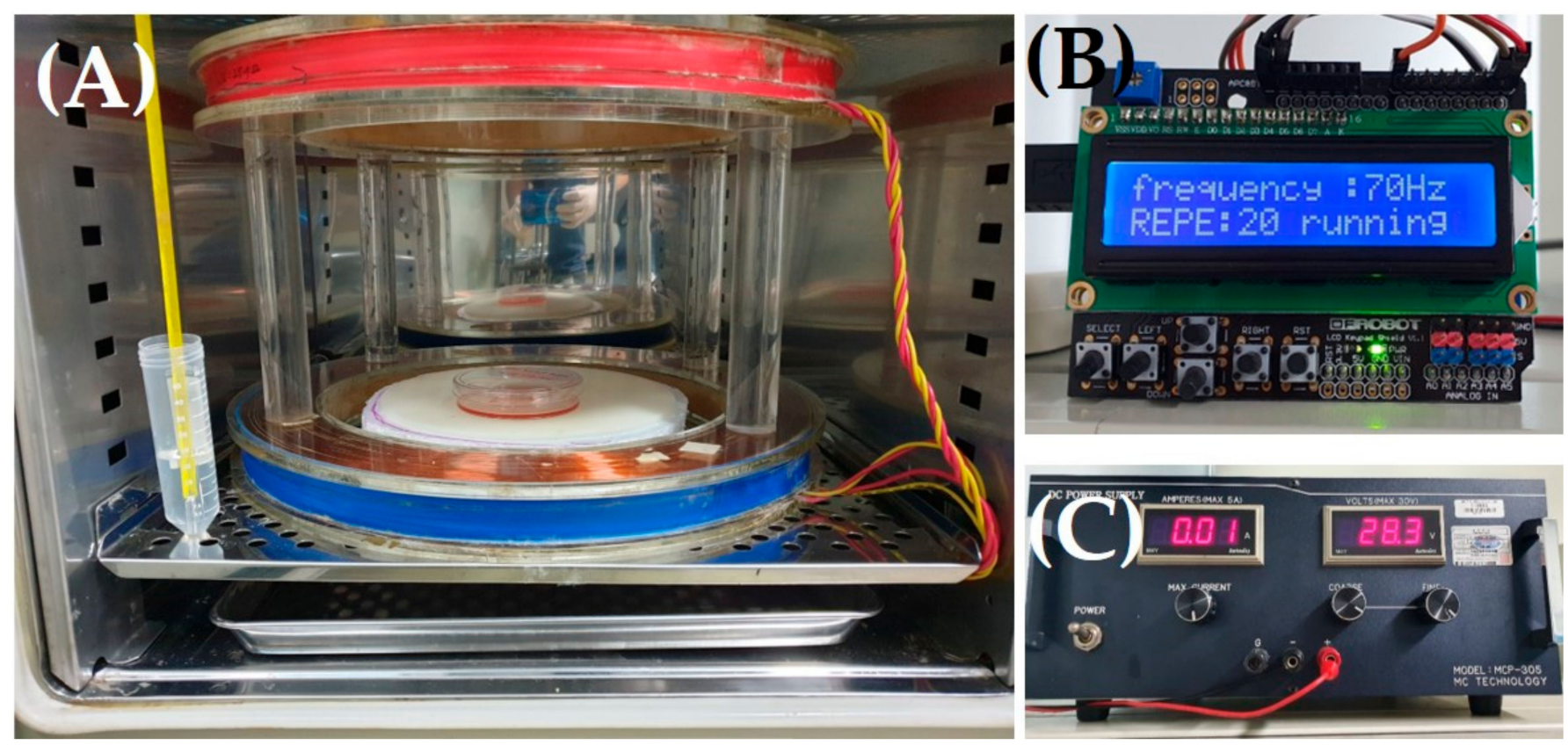

Figure 1. Image of the PEMF stimulation device. Helmholtz coils (A), a function generator set to 70 Hz ((B); 40, 60, 70, and $150 \mathrm{~Hz})$, and a power supply $(\mathbf{C})$ were used. Coils were placed in an incubator $\left(37^{\circ} \mathrm{C}, 5 \% \mathrm{CO}_{2}\right)$. PEMF; pulsed electromagnetic field.

\subsection{Cell Viability}

To evaluate cell viability, MTT analysis was performed after 3 days of culturing. Cell activity was assessed using the 3-(3,4-dimethylthiazol-2-yl)-2,5-diphenyltetrazolum bromide assay (MTT assay). Three days after the cells $\left(5 \times 10^{4}\right)$ were seeded in $35-\mathrm{mm}$ dishes, each dish was treated with an MTT solution $(5 \mathrm{mg} / \mathrm{mL})$, followed by incubation at $37^{\circ} \mathrm{C}$ for $90 \mathrm{~min}$. After incubation, the solution was replaced with dimethyl sulfoxide (Sigma-Aldrich) to dissolve the formazan. The absorbance of the resulting solution was measured at $570 \mathrm{~nm}$.

\subsection{Cytotoxicity Assay}

Cell cytotoxicity was measured by LDH assay (LDH assay kit, Takara Bio, Inc., Shiga, Japan) in preservation media, according to the manufacturer's protocol. MTT analysis was performed after 3 days of culturing.

\subsection{Cell Surface Antigen Analysis by FACS}

To analyze differentiation, hDPSCs were cultured in the same condition as described above (Sections 2.2 and 2.3) for 10 days. The cell surface markers present on hDPSCs were analyzed by flow cytometry. Briefly, hDPSCs were incubated with MSC-positive antibodies (CD73, CD105, and CD146, BioLegend, San Diego, CA, USA) for confirming differentiation. Cell suspensions in 5\% FBS without antibodies served as controls. The cells were washed three times with 5\% FBS to remove unbound antibodies and then resuspended with $200 \mu \mathrm{L}$ of $5 \%$ FBS. The cells were sorted using a flow cytometer (CytoFLEX, Beckman Coulter, Brea, CA, USA) and analyzed using CytExpert software (Beckman Coulter). 


\subsection{Western Blotting}

To evaluate protein expression, Western blotting was performed after 3 days of culturing. Whole-cell proteins were extracted as previously described [34]. Protein concentrations were determined by a bicinchoninic acid assay. Herein, $10 \mu \mathrm{g}$ of protein was separated at $90 \mathrm{~V}$ on $10 \%$ SDS-PAGE for $120 \mathrm{~min}$. The separated proteins were transferred onto a nitrocellulose membrane at $120 \mathrm{~V}$ for $90 \mathrm{~min}$ and then incubated with primary antibodies against ALP, Runx2, DMP-1, DSPP, $\beta$-catenin, GSK-3 $\beta$, p-GSK-3 $\beta$, p38, and p-p38 (all from Abcam). The membranes were incubated with $2 \mu \mathrm{g}$ of anti-mouse and anti-rabbit secondary antibodies in 5\% skimmed milk in TBS buffer for $1 \mathrm{~h}$ and applied to an enhanced chemiluminescence (ECL) solution for $1 \mathrm{~min}$. Then, autoradiography was performed using a ChemiDoc XRS+ Imaging System (Bio-Rad, Hercules, CA, USA). $\beta$-Actin served as an internal protein control.

\subsection{RT-PCR and Real-Time PCR Analysis}

To evaluate mRNA expression, RT-PCR analysis was performed after 3 days of culturing. TRIzol (Invitrogen, Waltham, MA, USA) was used to isolate total RNA from the cells. After adding $500 \mu \mathrm{L}$ of TRIzol reagent to a $60-\mathrm{mm}$ culture dish and collecting it in an e-tube, $200 \mu \mathrm{L}$ of chloroform was added into the e-tube, and the solution was vortexed and incubated for $5 \mathrm{~min}$. After centrifugation $\left(13,475 \times g, 4{ }^{\circ} \mathrm{C}, 15 \mathrm{~min}\right)$, the supernatant was transferred to a new tube, and $500 \mu \mathrm{L}$ of isopropanol was added. After a 10-min incubation and another centrifugation step $\left(18,340 \times g, 4^{\circ} \mathrm{C}, 10 \mathrm{~min}\right)$, the solution was discarded. The pellet was washed with $1 \mathrm{~mL}$ of $75 \%$ ethanol and centrifuged $\left(7580 \times g, 4{ }^{\circ} \mathrm{C}, 5 \mathrm{~min}\right)$. The solution was removed, and the pellet was air-dried. The pellet was dissolved in $20 \mu \mathrm{L}$ of RNase-free water (Welgene) and incubated on ice for $10 \mathrm{~min}$. Total RNA was determined using a NanoDrop spectrophotometer (Thermo Fisher Scientific, Waltham, MA, USA).

For the RT-PCR analysis, reverse transcriptase reactions were used to synthesize cDNA from $3 \mu \mathrm{g}$ of total RNA using an Advantage RT-PCR kit (Clontech Laboratories, Inc., Palo Alto, CA, USA) by following the manufacturer's protocols (Table 1). Test gene expressions were normalized against $\beta$-actin in each sample.

Table 1. PCR primer sequences. BMP2; bone morphogenetic protein 2, ALP; alkaline phosphatase, Runx2; runt-related transcription factor 2, OMD; osteomodulin, DMP-1; dentin matrix acidic phosphoprotein 1, DSPP; dentin sialophosphoprotein.

\begin{tabular}{cccccc}
\hline Gene & Forward $\left(\mathbf{5}^{\prime} \mathbf{- 3}^{\prime}\right)$ & Reverse $\left(\mathbf{5}^{\prime} \mathbf{-} \mathbf{3}^{\prime} \mathbf{)}\right.$ & Temp $\left.\mathbf{(}^{\circ} \mathbf{C}\right)$ & $\mathbf{C y c l e s}$ & $\mathbf{B a s e} \mathbf{P a i r}(\mathbf{b p})$ \\
\hline$\beta$-actin & GTGATGGTGGGCATGGGTCA & GCCGGACTCGTCATACTCCT & 58.0 & 37 & 972 \\
BMP2 & GTCCAGCTGTAAGAGACACC & GTACTAGCGACACCCACAAC & 58.5 & 28 & 316 \\
ALP & ATCTCGTTGTCTGAGTACCAGTCC & TGGAGCTTCAGAAGCTCAACACCA & 59.0 & 32 & 454 \\
Runx2 & ACAGTAGATGGACCTCGGGA & ATACTGGGATGAGGAATGCG & 55.0 & 30 & 113 \\
OMD & GCTATGGATGGGCTAGTAAAC & GGGATGTCTTGTAGTTTGTTGTG & 58.5 & 36 & 278 \\
DMP-1 & GAGTGGCTTCATTGGGCATAG & GACTCACTGCTCTCCAAGGG & 60.0 & 37 & 260 \\
DSPP & GGAATGGCTCTAAGTGGGCA & CTCATTGTGACCTGCATCGC & 60.0 & 37 & 284 \\
\hline
\end{tabular}

Additionally, for the real-time PCR analysis, reverse transcriptase reactions were used to synthesize cDNA from $2 \mu \mathrm{g}$ of total RNA using a dyne RT Dry MIX (Dyne Bio, Gyeonggi-do, Korea) by following the manufacturer's protocols. qPCR was performed using a TB Green ${ }^{\circledR}$ Premix Ex Taq ${ }^{\mathrm{TM}}$ (Tli RNaseH Plus) and a StepOnePlus Real-Time PCR System (Applied Biosystems, Waltham, MA, USA) with 60 cycles of denaturation at $95^{\circ} \mathrm{C}$ for $5 \mathrm{~s}$, annealing at $60^{\circ} \mathrm{C}$ for $25 \mathrm{~s}$, and amplification at $72{ }^{\circ} \mathrm{C}$ for $30 \mathrm{~s}$. Test gene expressions were normalized against GAPDH in each sample.

\subsection{Immunofluorescence}

To evaluate antigen expression, immunofluorescence staining was performed after 5 days of culturing. hDPSCs were grown on round, sterilized glass cover slips $(12 \mathrm{~mm})$. The cells were characterized for the markers of differentiated hDPSCs (DMP- 1 and $\beta$-catenin; Abcam). Briefly, the cells were washed with cold Dulbecco's phosphate-buffered saline 
(PBS), fixed in $4 \%$ paraformaldehyde for $10 \mathrm{~min}$, and washed twice in PBS with $0.1 \%$ Triton X-100 (PBS-T) for $5 \mathrm{~min}$. Afterward, the cells were incubated with primary antibodies diluted in 1\% bovine serum albumin (primary antibodies; DMP-1 and $\beta$-catenin, Abcam) overnight and then with appropriate secondary antibodies for $2 \mathrm{~h}$. After washing twice with PBS-T, the nuclei were stained with DAPI $(0.4 \mu \mathrm{g} / \mathrm{mL})$ at room temperature for $2 \mathrm{~min}$ in the dark. The cells were washed twice with PBS-T, mounted on clean slide glasses with Mount Fluor (BioCyc, Potsdam, Germany), and stored at $4{ }^{\circ} \mathrm{C}$. Representative images were captured using a Nikon Eclipse Ti microscope.

\subsection{Von Kossa Staining}

To evaluate calcium deposition, von Kossa staining was performed after 10 days of culturing. The cells were assessed using a 5\% silver nitrate (Sigma-Aldrich) solution under ultraviolet light for $20 \mathrm{~min}$, followed by a 5\% sodium thiosulphate (Sigma-Aldrich) solution for $5 \mathrm{~min}$, and then counterstained with a nuclear fast red solution (Sigma-Aldrich) for $10 \mathrm{~min}$. The mineral was stained black.

\subsection{Statistical Analysis}

Data are expressed as the mean \pm SEM of three independent experiments. One-way analysis of variance (ANOVA) followed by Tukey-Kramer multiple comparisons test was performed with GraphPad Prism (La Kolla, CA, USA). Mean differences were considered significant at $p<0.05\left({ }^{*} p<0.05,{ }^{* *} p<0.01\right.$, and $\left.{ }^{* *} p<0.005\right)$. Graphical representations were created using SigmaPlot (Systat Software, Inc., San Jose, CA, USA). All experiments were performed in triplicate.

\section{Results}

\subsection{Non-Cytotoxicity of PEMF Exposure}

We exposed hDPSCs to various frequencies $(40,60,70$, and $150 \mathrm{~Hz})$ of PEMF at an intensity of $10 \mathrm{mT}$ and performed lactate dehydrogenase (LDH) and mitochondrial activity (MTT) assays. Figure 2A shows the morphologies of hDPSCs in the control group and the PEMF-exposed groups after three days. All control and PEMF-treated groups, irrespective of the PEMF frequency, did not show apoptosis or necrosis (Figure 2A), and there were no differences in mitochondrial activities between the groups in the MTT assay (Figure 2(Ba)). Furthermore, the absence of significant differences in the amount of LDH released between the groups exposed to PEMF and the controls confirmed that PEMF did not induce cellular stress (Figure 2(Bb)).

\section{2. hDPSCs Were Differentiated by Media and PEMF}

Cell differentiation was evaluated by fluorescence-activated cell sorter (FACS) analysis of MSC-related cell surface proteins because hDPSCs express cell surface proteins similar to those of MSCs [35,36]. Three known MSC markers, namely CD73, CD105, and CD146, were used in FACS analysis to determine whether PEMF alters hDPSC surface antigen expression (Figure 3). The cell surface proteins were expressed in over $95 \%$ of the undifferentiated hDPSCs (data not shown). The results of cultures after five days showed the expression of $61.55 \pm 1.57 \%$ and $61.29 \pm 0.32 \%$ CD73, $29.24 \pm 6.51 \%$ and $29.33 \pm 4.34 \%$ CD105, and $32.41 \pm 2.16 \%$ and $30.19 \pm 3.24 \%$ CD146 at 60 and $70 \mathrm{~Hz}$, respectively, and $77.21 \pm 1.47 \%$ CD73, $43.46 \pm 1.09 \%$ CD105, and $40.38 \pm 0.53 \%$ CD146 expression in the control group (Figure 2A). All surface antigens were decreased in all groups after 10 days, particularly the cells exposed to 60 and $70 \mathrm{~Hz}$ PEMF (Figure 3B), which indicates that some frequencies of PEMF may cause changes in hDPSC surface antigen expression. The FACS percentages are shown in Table 2. 


\section{(A)}
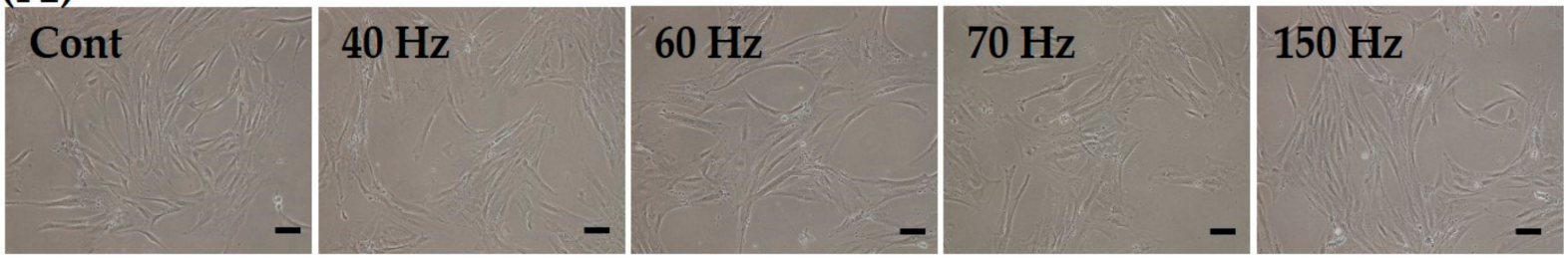

(B)
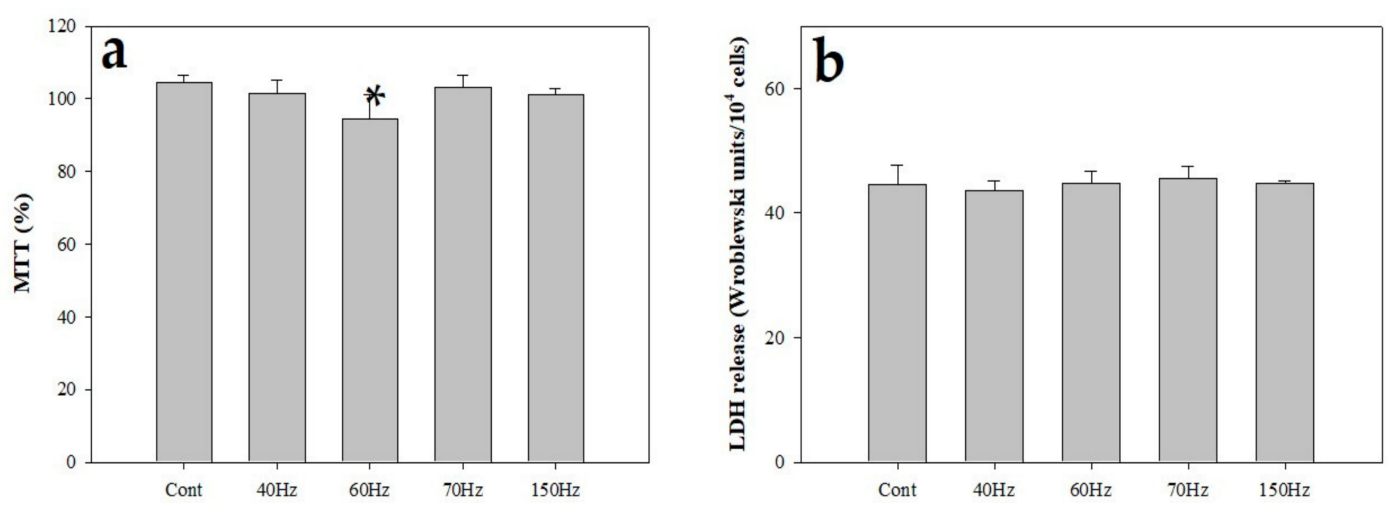

Figure 2. (A) Morphologies of human dental pulp stem cells (hDPSCs) after PEMF exposure for 3 days (10 mT). All groups were incubated with the same medium-odontoblastic differentiation medium. Each group had different frequency conditions $(40,60,70$, and $150 \mathrm{~Hz})$. Scale bar $=100 \mu \mathrm{m}$. (B) Cell viability (a; MTT assay) and stress (b; LDH assay) of hDPSCs at 3 days. ${ }^{*} p<0.05$ (compared with the control). PEMF; pulsed electromagnetic field; MTT; 3-(3,4-dimethylthiazol2-yl)-2,5-diphenyltetrazolum bromide, LDH; lactate dehydrogenase. Cont = control (no PEMF treatment).

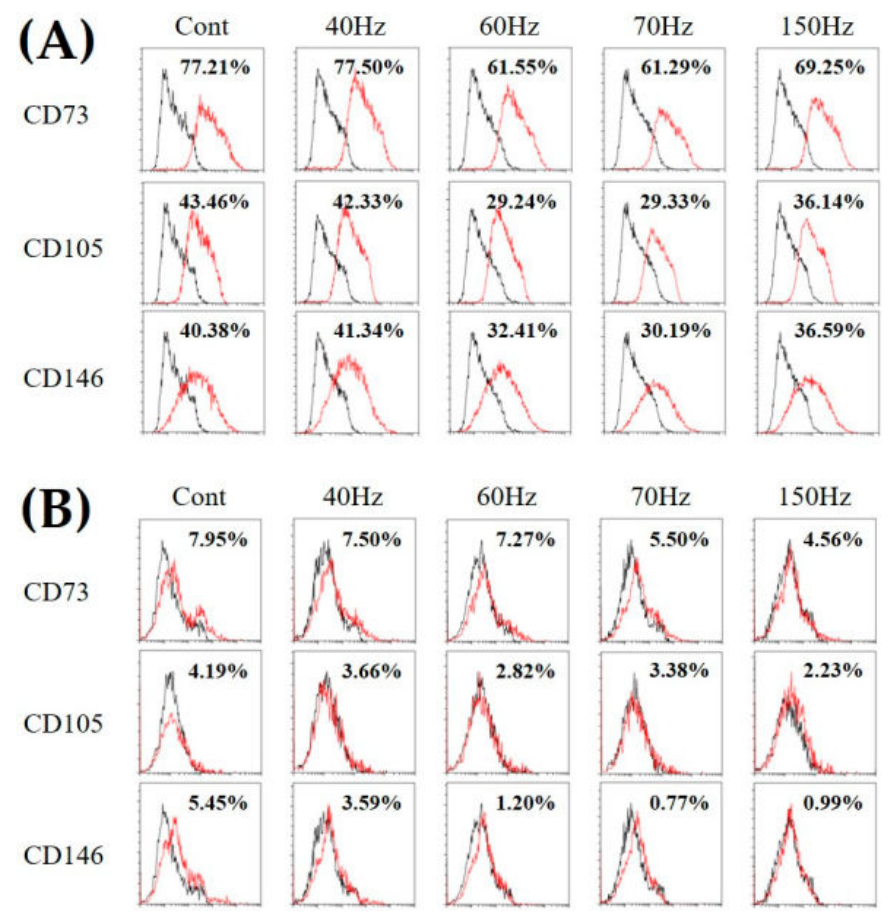

Figure 3. Fluorescence-activated cell sorter analysis of the surface markers CD73, CD105, and CD146 after PEMF exposure for 5 days (A) and 10 days (B). hDPSCs were labeled with phosphatidylethanolamine-conjugated antibodies and then analyzed in a flow cytometer. hDPSCs; human dental pulp stem cells. Cont = control (no PEMF treatment). Black line: FITC- or PE-conjugated IgG1, Red line: FITC- or PE-conjugated anti-body. 
Table 2. FACS analysis of mesenchymal stem cell markers. FACS data percentage-upper values in each row; 5 days of PEMF exposure, lower values in each row; 10 days of PEMF exposure. Cont = control (no PEMF treatment).

\begin{tabular}{ccccccc}
\hline \multicolumn{2}{c}{ Markers $\%$} & Cont & $\mathbf{4 0 ~ H z}$ & $\mathbf{6 0 ~ H z}$ & $\mathbf{7 0 ~ H z}$ & $\mathbf{1 5 0 ~ H z}$ \\
\hline \multirow{2}{*}{ CD73 } & 5 D & $77.21 \pm 1.47$ & $77.50 \pm 4.72$ & $61.55 \pm 1.57^{* * *}$ & $61.29 \pm 0.32 * * *$ & $69.25 \pm 2.71 *$ \\
& 10 D & $7.95 \pm 0.34$ & $7.50 \pm 2.14$ & $7.27 \pm 3.29$ & $5.50 \pm 1.97$ & $4.56 \pm 2.12$ \\
\hline \multirow{2}{*}{ CD105 } & 5 D & $43.46 \pm 1.09$ & $42.33 \pm 2.87$ & $29.24 \pm 6.51^{*}$ & $29.33 \pm 4.34^{*}$ & $36.14 \pm 3.76^{*}$ \\
& $10 \mathrm{D}$ & $4.19 \pm 0.49$ & $3.66 \pm 1.22$ & $2.82 \pm 1.07$ & $3.38 \pm 0.92$ & $2.23 \pm 1.04^{*}$ \\
\hline \multirow{2}{*}{ CD146 } & 5 D & $40.38 \pm 0.53$ & $41.34 \pm 1.29$ & $32.41 \pm 2.16^{* *}$ & $30.19 \pm 3.24^{* *}$ & $36.59 \pm 4.24$ \\
& 10 D & $5.54 \pm 2.31$ & $3.59 \pm 1.25$ & $1.20 \pm 0.46^{*}$ & $0.77 \pm 0.13^{*}$ & $0.99 \pm 0.40^{*}$ \\
\hline
\end{tabular}

${ }^{*} p<0.05,{ }^{* *} p<0.01, * * * p<0.005$.

\subsection{PEMF Exposure-Induced High Expression of Odontoblast-Related Molecules}

Markers related to odontoblastic differentiation were generally increased in the cells exposed to PEMF (Figure 4). The frequency of $70 \mathrm{~Hz}$ showed a particularly high expression of these markers (1.4-fold in runt-related transcription factor 2 (Runx2), 6.4-fold in DMP-1, and 1.6-fold in DSPP). Similarly, the cells exposed to $60 \mathrm{~Hz}$ PEMF showed high expression as well (3.3-fold in ALP, 1.3-fold in Runx2, 4.1-fold in DMP-1, and 1.3-fold in DSPP). Western blotting results showed that gene expressions of DMP-1 and DSPP were generally higher at 60 and $70 \mathrm{~Hz}$ than those in the other groups, and the cells exposed to $60 \mathrm{~Hz}$ PEMF expressed the highest $A L P$ levels.
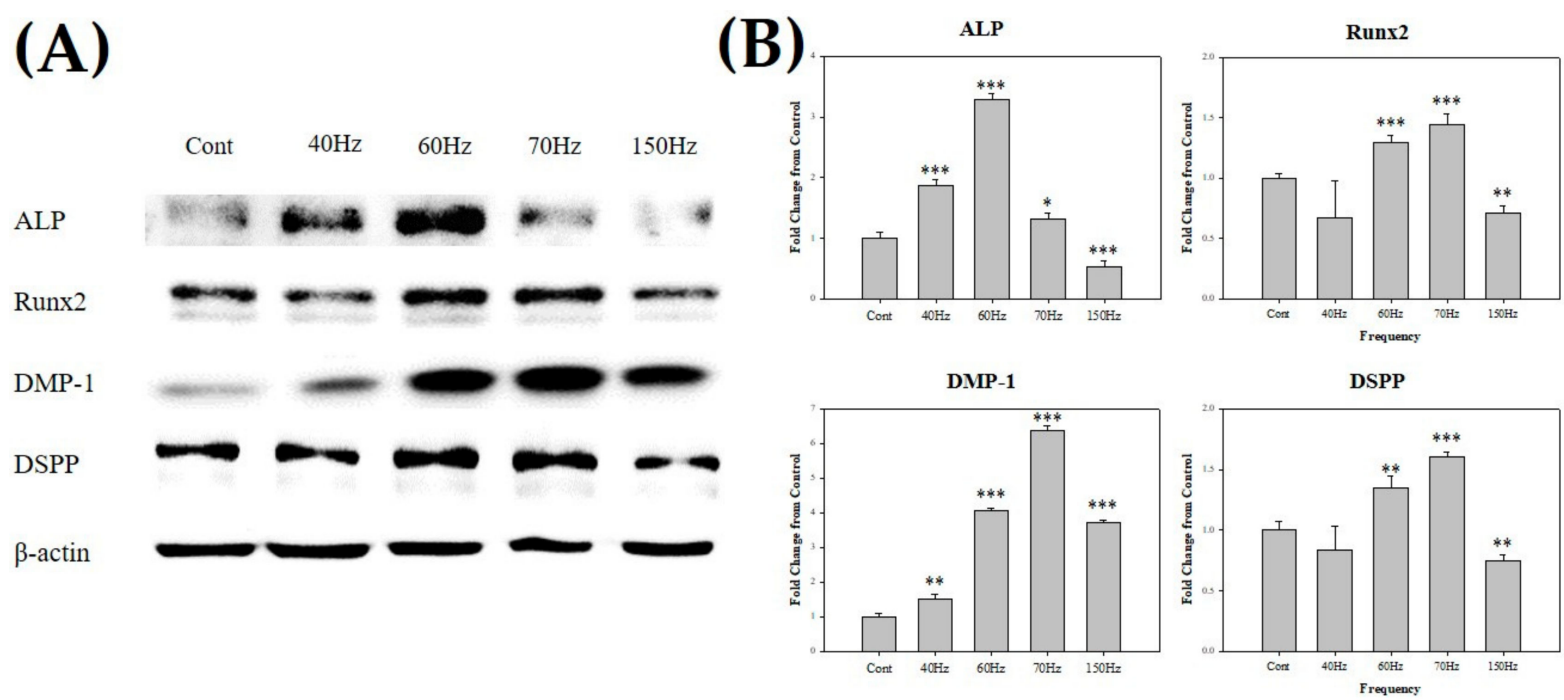

Figure 4. (A) Western blot of ALP, Runx2, DMP-1, DSPP, and $\beta$-actin after exposure to 10 mT PEMF for 3 days. (B) All markers were increased in the cells exposed to PEMF. Each target protein was normalized to $\beta$-actin. Notably, most markers were expressed at 60 and $70 \mathrm{~Hz} .{ }^{*} p<0.05,{ }^{* *} p<0.01,{ }^{* * *} p<0.005$ (compared with the control). ALP; alkaline phosphatase, Runx2; runt-related transcription factor 2, DMP-1; dentin matrix acidic phosphoprotein 1, DSPP; dentin sialophosphoprotein, ACTB; $\beta$-actin, PEMF; pulsed electromagnetic field. Cont = control (no PEMF treatment).

As shown in Figure 5A, all odontogenic genes (bone morphogenetic protein (BMP) 2, $A L P$, Runx2, osteomodulin (OMD), DMP-1, and DSPP) were expressed more in PEMFexposed cells than in the controls based on reverse transcriptase-polymer chain reaction (RT-PCR) analysis. BMP, OMD, Runx2, and DSPP expression had slight but not statistically significant differences in frequency. However, the frequency of 60 and $70 \mathrm{~Hz}$ showed a high expression in ALP and DMP-1 markers compared to those of the other frequency, and the difference was statistically significant. 


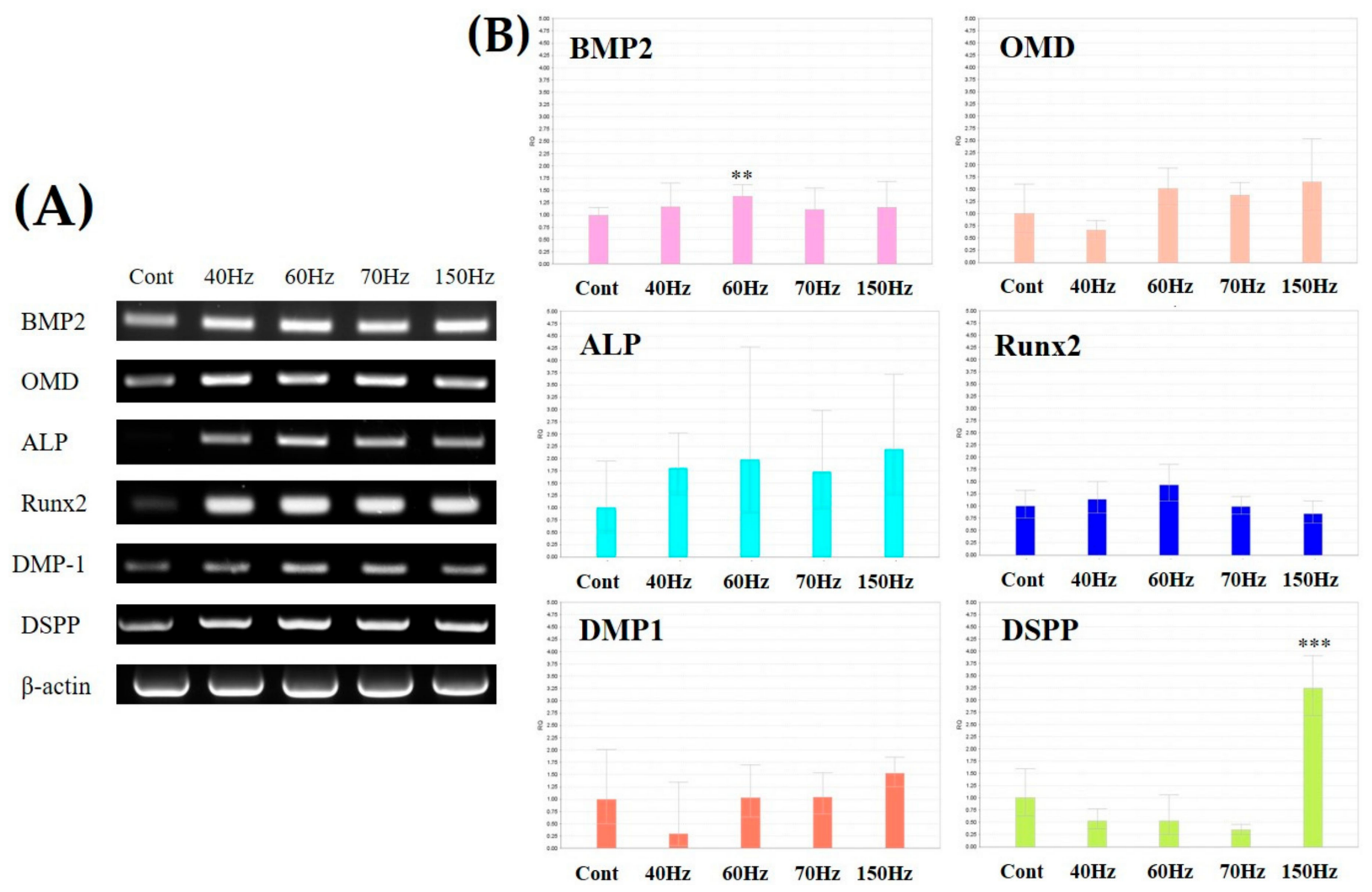

Figure 5. (A) RT-PCR analysis of $B M P 2, A L P$, Runx2, OMD, DMP-1, DSPP, and ACTB after PEMF exposure for 3 days. (B) Real time-PCR analysis for odontoblast-related marker. All markers were increased in the cells exposed to PEMF. ${ }^{* *} p<0.01,{ }^{* * *} p<0.005$ (compared with the control). BMP2; bone morphogenetic protein 2, OMD; osteomodulin, $A L P$; alkaline phosphatase, Runx2; runt-related transcription factor 2, DMP-1; dentin matrix acidic phosphoprotein 1, DSPP; dentin sialophosphoprotein, ACTB; $\beta$-actin, PEMF; pulsed electromagnetic field. Cont = control (no PEMF treatment).

However, real-time PCR results differ from RT-PCR. For BMP, OMD, ALP, and Runx2 expression, there was a slight increase in the EMP-exposure groups compared to the nonexposure group, but there were no statistical differences. In particular, DSPP showed a slight decrease in expression compared to that in non-exposure group groups but increased expression at $150 \mathrm{~Hz}$ (Figure 5B). As a result, no statistical differences were observed in the expression of odontoblast-related mRNA by EMF-exposure.

\subsection{DMP-1 and $\beta$-Catenin Increased in Nucleus and Cytoplasm of Cells Exposed to PEMF of Certain Frequency}

hDPSCs were treated with PEMF at various frequencies, and the expression of DMP-1 and $\beta$-catenin was measured via immunofluorescence staining (Figure 6). Beta-catenin was upregulated at 60 and $70 \mathrm{~Hz}$, and DMP- 1 also showed increased expression at these frequencies. In particular, the expression of both proteins increased noticeably at $70 \mathrm{~Hz}$ in merged images of DMP-1, $\beta$-catenin, and 4',6-diamidino-2-phenylindole (DAPI).

\subsection{PEMF Exposure at Certain Frequencies Promotes Odontoblast-Related Proteins through Phosphorylation of Glycogen Synthase Kinase-3 Beta $(G S K-3 \beta) / \beta$-Catenin}

We aimed to determine whether GSK-3 $\beta / \beta$-catenin signaling was involved in the differentiation of hDPSCs and the expression of odontoblast-related proteins caused by PEMF. As seen in Figure 7, PEMF increased the overall phosphorylation of GSK-3 $\beta / \beta$-catenin significantly. Furthermore, phosphorylated-GSK-3 $\beta$ (p-GSK-3 $\beta$ (Ser9)) and phosphorylatedp38 (p-p38) levels increased markedly by approximately 1.9- and 1.8-fold after treatment with $70 \mathrm{~Hz}$ PEMF, respectively. The expression of $\beta$-catenin, a transcription coactivator known to affect odontoblast differentiation in GSK- $3 \beta / \beta$-catenin signaling, increased by about 9.5-fold at $60 \mathrm{~Hz}$ and 15.0-fold at $70 \mathrm{~Hz}$. These data collectively showed that PEMF 
induced hDPSC differentiation and increased odontoblast-related protein expression levels via the pathway mediated by GSK-3 $\beta / \beta$-catenin signaling.

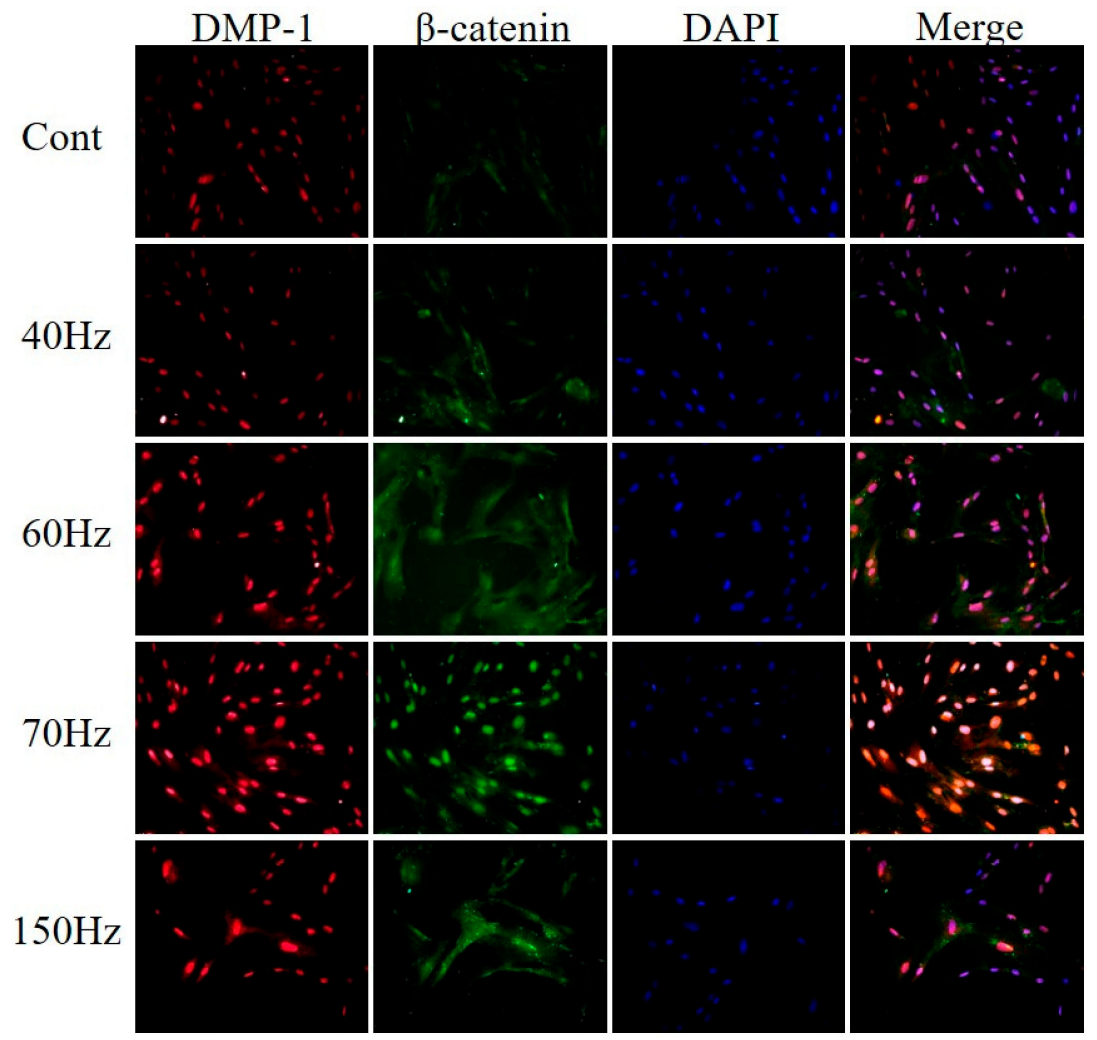

Figure 6. Effects of PEMF exposure on hDPSC odontogenesis as determined by immunofluorescence of DMP- 1 and $\beta$-catenin at 5 days. DMP- 1 and $\beta$-catenin expressions were visibly increased in PEMF-stimulated cells. PEMF; pulsed electromagnetic field, hDPSC; human dental pulp stem cell, DMP-1; dentin matrix acidic phosphoprotein 1. Cont $=$ control (no PEMF treatment).

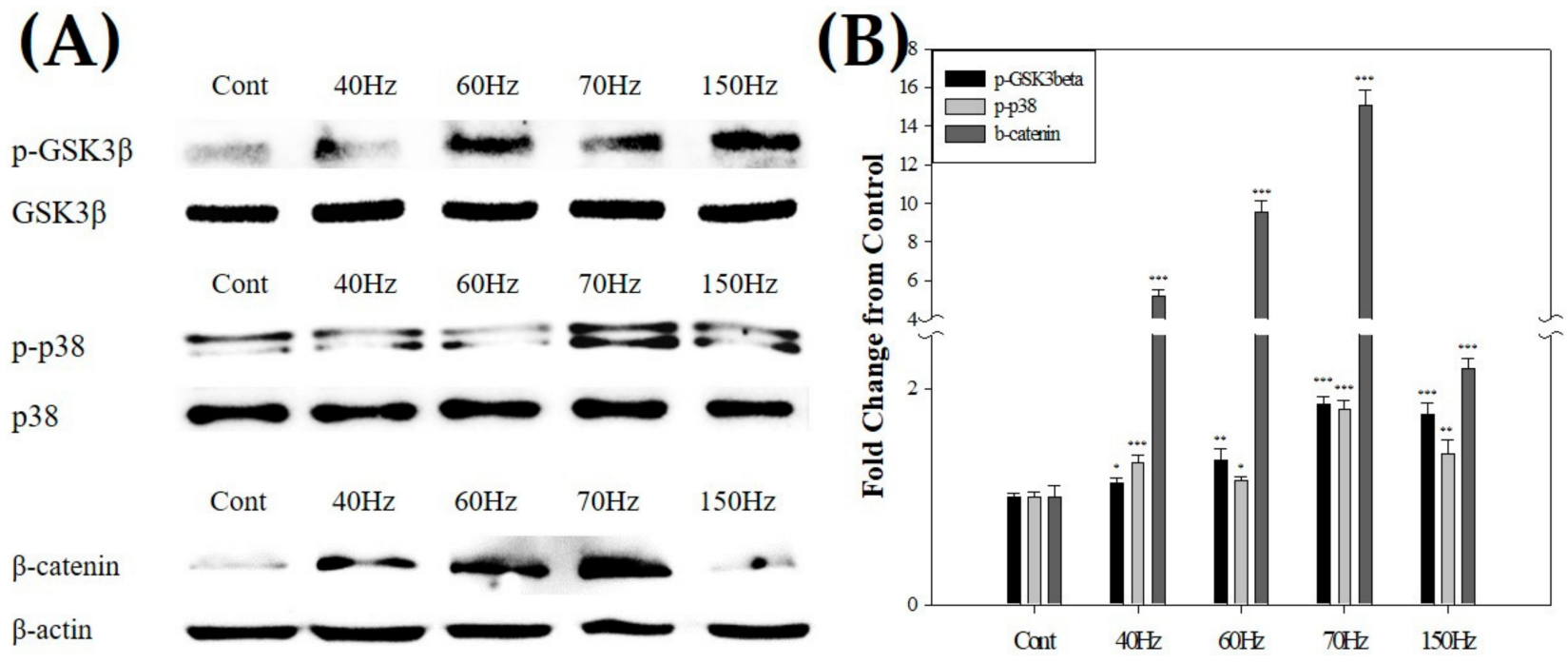

Figure 7. (A) Western blot of $\beta$-catenin, p-GSK3 $\beta$, and p-p38 after 10 mT PEMF exposure for 3 days. (B) All markers were increased in the cells exposed to PEMF. PEMF-exposed groups had higher expression than the control group. ${ }^{*} p<0.05$, ${ }^{* *} p<0.01,{ }^{* * *} p<0.005$ (compared with the control). p-GSK3 $\beta$; phosphorylated-glycogen synthase kinase-3 beta, p-p38; phosphorylated-p38, PEMF; pulsed electromagnetic field. Cont = control (no PEMF treatment). 


\subsection{Increased Calcium Deposition by PEMF Exposure}

The von Kossa staining performed for the evaluation of the calcium deposition of the hDPSC during differentiation (Figure 8). In the growth media culture group, no mineral deposited on the cell surface was observed at all. The EMF-exposed groups exhibited a small amount of matrix mineralization, while the non-exposed (control) group exhibited little matrix mineralization compared with the other groups on Day 10. Not enough mineral deposition was observed due to the short culture period of the cells. However, mineral deposition was formed along the cytoplasm and was observed on the cell surface. At frequency above $60 \mathrm{~Hz}$, the minor deposition difference was not identified.

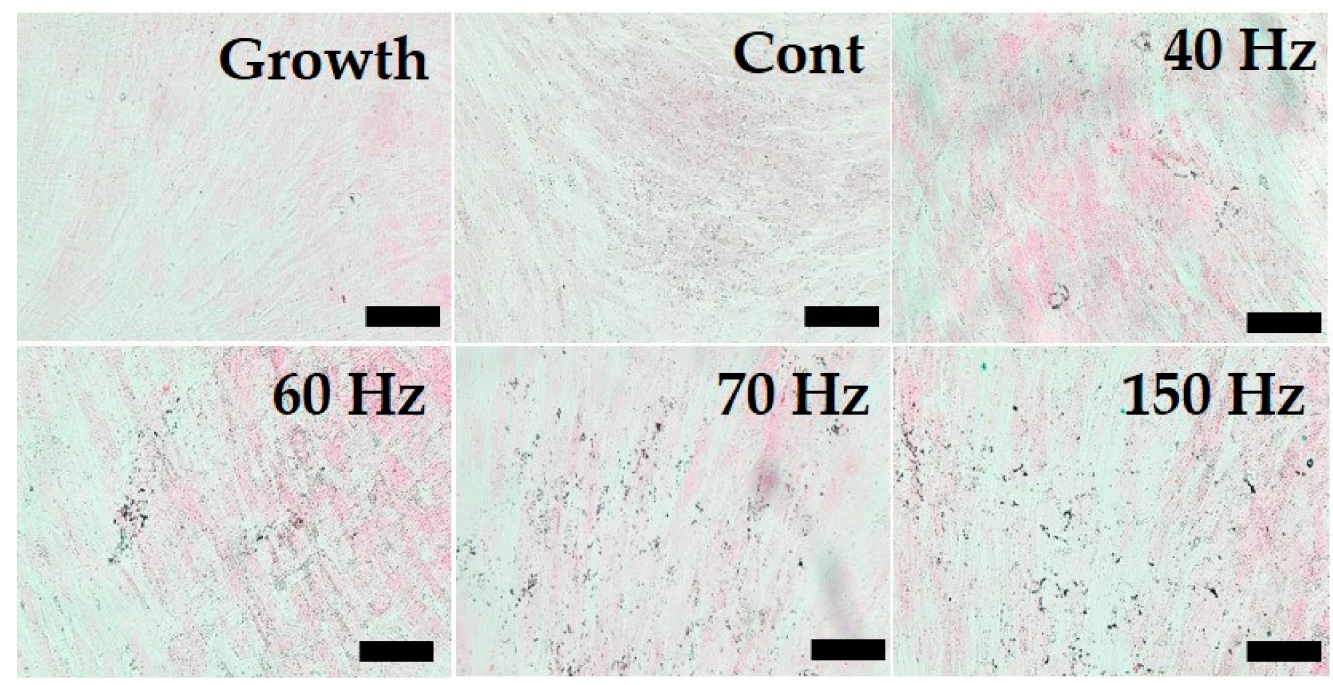

Figure 8. Effects of PEMF exposure on calcium deposition as determined by von Kossa staining at 10 days. Mineral detections were increased in PEMF-stimulated cells. PEMF; pulsed electromagnetic field, hDPSC; human dental pulp stem cell, Cont = control (no PEMF treatment). Growth = growth media (no PEMF treatment). Original magnification: $\times 200$, bar $=100 \mu \mathrm{m}$.

\section{Discussion}

EMF is known to be non-invasive and non-toxic and exerts diverse biological effects on the activity, growth, and differentiation of various cell types [37-40]. The purpose of this study was to identify the effects of various frequencies of PEMF on hDPSCs and also determine the optimal condition that would promote their differentiation into odontoblastlike cells. To our knowledge, this is the first study on the use of PEMF for odontogenesis.

After three days of incubation with PEMF exposure, cell activity remained similar at all frequencies without affecting mitochondrial activities (Figure 2(Ba)). We observed cell morphology and performed the LDH assay to check for cytotoxicity. No morphological changes in the cell membrane and no cytotoxicity, such as vacuole or signs of apoptosis, were observed following PEMF exposure at any frequency (Figure 2(Bb)).

Some investigators have reported that high-frequency magnetic exposure can induce mitochondrial DNA damage, reactive oxygen species, and cell apoptosis. For example, EMF of $8 \mathrm{mT}(50 \mathrm{~Hz})$ and long time (eight hours per day for eight weeks) induced an increase in mitochondrial damage and ultra-structure changes [41,42], and EMF of $10 \mathrm{mT}$ $(50 \mathrm{~Hz})$ and long time (24 hours per day for three weeks) increased stress and abnormal behavior in rat models [43]. However, another study showed that EMF exposure of $16 \mathrm{mT}$ $(15 \mathrm{~Hz})$ and short time (eight hours a day for 24 days) increased osteoblastic differentiation of MSCs [44]. These findings indicate that the effect of EMF on cells or animals can be regulated by the applied frequency, intensity, and exposure time [45]. According to the results of the LDH and MTT assays in the current work, although the intensity $(10 \mathrm{mT})$ was high, the short exposure (15 min/day) time showed that PEMF did not cause cell damage and stress. 
hDPSCs are known as adult stem cells. Both their features and the expression of their cell surface proteins are similar to those of MSCs [36]. Based on this, the cells were analyzed using FACS with CD73, CD105, and CD146 as the representative surface markers of MSCs because these markers decrease when MSCs differentiate into specific cell types [46-49]. On day five of culturing, the cells exposed to 60 and $70 \mathrm{~Hz}$ PEMF expressed all three MSC markers at levels about $10 \%$ lower relative to those of the control (Figure 3A). On day 10 of culturing, most of these levels had declined to below $10 \%$, indicating the differentiation of hDPSCs (Figure 3B). In particular, the expression levels were lower in the cells exposed to 60 and $70 \mathrm{~Hz}$ PEMF than in the control group. Consequently, the expression levels of the cell surface markers decreased regardless of whether the cells were exposed or not exposed to PEMF, and these results indicate cell differentiation.

Figure 4 shows the protein expressions in each experimental group. ALP is a critical marker of osteo/odontoblastic differentiation and associated with mineralization [50-52]. Here, ALP showed high expression at $60 \mathrm{~Hz}$. Runx2 was more expressed in the hDPSCs exposed to 60 and $70 \mathrm{~Hz}$ PEMF compared with the control group. Furthermore, the increase in the expression of Runx2, which is related to the repair of dental pulp damage, regulated the odontoblastic differentiation of hDPSCs $[53,54]$. DMP-1 and DSPP play key roles in dentin mineralization and maturation as major markers of odontoblasts and have been previously used to determine odontoblast-like differentiation [12,14,55-57]. In our study, DMP-1 was significantly expressed at $70 \mathrm{~Hz}$ and was high at other frequencies as well. Similarly, DSPP showed high expression at 60 and $70 \mathrm{~Hz}$. Immunofluorescence showed that the expression of DMP-1 in both cytoplasm and nucleus was high at $70 \mathrm{~Hz}$ (Figure 6).

Through RT-PCR, we analyzed the expression of odontoblastic differentiation-related genes (Figure 5). BMP2 is an important regulator of the differentiation process because it promotes odontoblastic differentiation and supports forming mineralized nodules [58-60]. $B M P 2$ gene expression was increased in the cells that were exposed to PEMF at $60 \mathrm{~Hz}$. $O M D$ was also expressed in cells exposed to any frequency. Interestingly, Lin et al. demonstrated that knockdown of $O M D$ reduced mineralized nodule formation and inhibited osteo/odontoblastic differentiation [61]. Regarding protein expressions, ALP, Runx2, DMP1 , and DSPP showed increased expression in hDPSCs exposed to PEMF at any frequency. The effect of odontoblast-related protein and gene expression may lead to the differentiation of hDPSCs exposed to PEMF.

Figure 7 shows the significantly increased expression of $\beta$-catenin at $70 \mathrm{~Hz}$. It was also verified that the phosphorylation of GSK-3 $\beta$ and p38 associated with the activation of $\beta$-catenin increased at $70 \mathrm{~Hz}$ (Figure 7). $\beta$-Catenin regulates the proliferation and differentiation of various cells, which is exemplified by its roles in osteogenesis and hair growth $[62,63]$. Han et al. induced tooth regeneration by odontoblastic differentiation in their experiments with rat teeth and cells, and confirmed by immunofluorescence that catenin protein and gene expression increased [53]. It is well-known that active $\beta$-catenin is transferred from the cytoplasm to the nucleus and plays a crucial role in dentinogenesis due to the proliferation and odontoblastic differentiation of hDPSCs [64]. Similar to osteogenesis, odontoblast differentiation also occurs through the GSK-3 $\beta$ / $\beta$-catenin pathway. In vivo, GSK-3 $\beta$ suppression temporarily increased bone formation, weakened bone degradation, and inhibited osteolysis induced by mechanical instability of the implants [65]. Additionally, the canonical Wnt $\beta$-catenin pathway inhibits GSK-3 $\beta$ activity, which leads to the accumulation of $\beta$-catenin in the cytosol and its subsequent translocation to the nucleus [66]. Odontoblastic differentiation was promoted through the WNT, p38 mitogenactivated protein kinase (MAPK), and BMP signaling pathways [67] and suppressed by the repression of $\mathrm{p}-\mathrm{GSK}-3 \beta$ and $\beta$-catenin [68]. Disruption of p38 can affect the integration factors required for various signal inputs. In vivo, p38 deletion inhibits osteoblast terminal differentiation and the appearance of osteocytes, which directly affects bone composition and maintenance [69]. Yun et al. differentiated hDPSCs into odontoblast-like cells using a differentiation medium on a nanofiber scaffold and confirmed to the activity of p38 MAPK signaling by analyzing the protein expression. The results confirmed that p38 MAPK sig- 
naling was activated, and p-GSK-3 $\beta$ was increased when hDPSCs were differentiated into odontoblast-like cells [70]. Combining the known information with our findings, we can conclude that PEMF modulates the differentiation of hDPSCs into odontoblasts through the $\mathrm{p} 38$ MAPK signaling pathway and the GSK-3 $\beta / \beta$-catenin pathway.

\section{Conclusions}

Based on the results, the characteristics of odontoblasts were well-expressed after exposure to $70 \mathrm{~Hz}$ PEMF for $15 \mathrm{~min}$. Consequently, we have demonstrated for the first time that hDPSCs can effectively differentiate into odontoblast-like cells when exposed to PEMF. Short-term PEMF exposure methods have suggested the possibility of incorporating PEMF therapy into future dentin regeneration. In addition, non-invasive and non-toxic PEMF will provide new methods for periodontal therapy.

Author Contributions: Conceptualization, H.-M.L. and Y.-K.S.; formal analysis, H.-M.L., Y.-M.K., and Y.-M.K.; investigation, H.-M.L. and M.-H.N.; writing-original draft, H.-M.L. and Y.-M.K.; writing-review and editing, supervision, Y.-K.S.; project administration, Y.-K.S. All authors have read and agreed to the published version of the manuscript.

Funding: This research was funded by the Basic Science Research Program through the National Research Foundation of Korea (NRF) funded by the Ministry of Education, grant number 2019R1I1A2A01063305.

Institutional Review Board Statement: Not applicable.

Informed Consent Statement: Not applicable.

Data Availability Statement: The data generated and analyzed during this study is available from the corresponding author on reasonable request.

Conflicts of Interest: The authors declare no conflict of interest.

\section{References}

1. Grawish, M.E.; Grawish, L.M.; Grawish, H.M.; Grawish, M.M.; El-Negoly, S.A. Challenges of Engineering Biomimetic Dental and Paradental Tissues. Tissue Eng. Regen. Med. 2020, 17, 403-421. [CrossRef]

2. Han, M.-J.; Seo, Y.-K.; Yoon, H.-H.; Song, K.-Y.; Park, J.-K. Upregulation of bone-like extracellular matrix expression in human dental pulp stem cells by mechanical strain. Biotechnol. Bioprocess Eng. 2010, 15, 572-579. [CrossRef]

3. Li, Y.; Nan, X.; Zhong, T.-Y.; Li, T.; Li, A.J.T.E.; Medicine, R. Treatment of Periodontal Bone Defects with Stem Cells from Inflammatory Dental Pulp Tissues in Miniature Swine. Tissue Eng. Regen. Med. 2019, 16, 191-200. [CrossRef] [PubMed]

4. Cao, H.-L.; Chung, J.-H.; Choung, P.-H. Allogeneic Fibrin Clot for odontogenic/Cementogenic Differentiation of Human Dental Mesenchymal Stem Cells. Tissue Eng. Regen. Med. 2020, 17, 511-524. [CrossRef] [PubMed]

5. Cui, X.; Chen, L.; Xue, T.; Yu, J.; Liu, J.; Ji, Y.; Cheng, L. Human umbilical cord and dental pulp-derived mesenchymal stem cells: Biological characteristics and potential roles in vitro and in vivo. Mol. Med. Rep. 2015, 11, 3269-3278. [CrossRef]

6. Hokmabad, V.R.; Davaran, S.; Aghazadeh, M.; Alizadeh, E.; Salehi, R.; Ramazani, A.J. A comparison of the effects of silica and hydroxyapatite nanoparticles on poly ( $\varepsilon$-caprolactone)-poly (ethylene glycol)-poly ( $\varepsilon$-caprolactone)/chitosan Nanofibrous scaffolds for bone tissue engineering. Tissue Eng. Regen. Med. 2018, 15, 735-750. [CrossRef] [PubMed]

7. Tjäderhane, L.; Haapasalo, M.J.E.T. The dentin-pulp border: A dynamic interface between hard and soft tissues. Endod. Top. 2009, 20, 52-84. [CrossRef]

8. Baldión, P.A.; Velandia-Romero, M.L.; Castellanos, J.E. Odontoblast-like cells differentiated from dental pulp stem cells retain their phenotype after subcultivation. Int. J. Cell Biol. 2018, 2018, 6853189. [CrossRef]

9. Narayanan, K.; Gajjeraman, S.; Ramachandran, A.; Hao, J.; George, A. Dentin matrix protein 1 regulates dentin sialophosphoprotein gene transcription during early odontoblast differentiation. J. Biol. Chem. 2006, 281, 19064-19071. [CrossRef]

10. Kim, S.G.; Zheng, Y.; Zhou, J.; Chen, M.; Embree, M.C.; Song, K.; Jiang, N.; Mao, J.J. Dentin and dental pulp regeneration by the patient's endogenous cells. Endod. Top. 2013, 28, 106-117. [CrossRef]

11. Angelova, A.V.; Zaugg, L.K.; Neves, V.; Liu, Y.; Sharpe, P.T. Tooth Repair and Regeneration. Curr. Oral Health Rep. 2018,5 , $295-303$. [CrossRef]

12. Suzuki, S.; Haruyama, N.; Nishimura, F.; Kulkarni, A.B. Dentin sialophosphoprotein and dentin matrix protein-1: Two highly phosphorylated proteins in mineralized tissues. Arch. Oral Biol. 2012, 57, 1165-1175. [CrossRef] [PubMed]

13. Chen, Z.; Li, W.; Wang, H.; Wan, C.; Luo, D.; Deng, S.; Chen, H.; Chen, S. Klf10 regulates odontoblast differentiation and mineralization via promoting expression of dentin matrix protein 1 and dentin sialophosphoprotein genes. Cell Tissue Res. 2016, 363, 385-398. [CrossRef] [PubMed] 
14. Tian, S.; Wang, J.; Dong, F.; Du, N.; Li, W.; Song, P.; Liu, Y. Concentrated Growth Factor Promotes Dental Pulp Cells Proliferation and Mineralization and Facilitates Recovery of Dental Pulp Tissue. Med. Sci. Monit. Int. Med. J. Exp. Clin. Res. 2019, $25,10016$. [CrossRef]

15. Caiaffa, K.S.; Basso, F.G.; Santos-Filho, N.A.; de Souza-Costa, C.A.; Sakai, V.T.; Cilli, E.M.; Duque, C. Effect of analogues of cationic peptides on dentin mineralization markers in odontoblast-like cells. Arch. Oral Biol. 2019, 103, 19-25. [CrossRef]

16. Murakami, M.; Hayashi, Y.; Iohara, K.; Osako, Y.; Hirose, Y.; Nakashima, M. Trophic effects and regenerative potential of mobilized mesenchymal stem cells from bone marrow and adipose tissue as alternative cell sources for pulp/dentin regeneration. Cell Transplant. 2015, 24, 1753-1765. [CrossRef] [PubMed]

17. Jiang, H.B.; Tian, W.D.; Liu, L.K.; Xu, Y. In vitro odontoblast-like cell differentiation of cranial neural crest cells induced by fibroblast growth factor 8 and dentin non-collagen proteins. Cell Biol. Int. 2008, 32, 671-678. [CrossRef]

18. Miyashita, S.; Ahmed, N.E.M.B.; Murakami, M.; Iohara, K.; Yamamoto, T.; Horibe, H.; Kurita, K.; Takano-Yamamoto, T.; Nakashima, M. Mechanical forces induce odontoblastic differentiation of mesenchymal stem cells on three-dimensional biomimetic scaffolds. J. Tissue Eng. Regen. Med. 2017, 11, 434-446. [CrossRef]

19. Li, Z.-Y.; Chen, L.; Liu, L.; Lin, Y.-F.; Li, S.-W.; Tian, W.-D. Odontogenic potential of bone marrow mesenchymal stem cells. J. Oral Maxillofac. Surg. 2007, 65, 494-500. [CrossRef]

20. Liao, C.; Ou, Y.; Wu, Y.; Zhou, Y.; Liang, S.; Wang, Y. Sclerostin inhibits odontogenic differentiation of human pulp-derived odontoblast-like cells under mechanical stress. J. Cell. Physiol. 2019, 234, 20779-20789. [CrossRef]

21. Kim, Y.-M.; Cho, S.-E.; Kim, S.-C.; Jang, H.-J.; Seo, Y.-K. Effects of extremely low frequency electromagnetic fields on melanogenesis through p-ERK and p-SAPK/JNK pathways in human melanocytes. Int. J. Mol. Sci. 2017, 18, 2120. [CrossRef]

22. D'Angelo, C.; Costantini, E.; Kamal, M.; Reale, M. Experimental model for ELF-EMF exposure: Concern for human health. Saudi J. Biol. Sci. 2015, 22, 75-84. [CrossRef]

23. Hei, W.H.; Kim, S.; Park, J.C.; Seo, Y.K.; Kim, S.M.; Jahng, J.W.; Lee, J.H. Schwann-like cells differentiated from human dental pulp stem cells combined with a pulsed electromagnetic field can improve peripheral nerve regeneration. Bioelectromagnetics 2016, 37, 163-174. [CrossRef] [PubMed]

24. Bao, Z.; Fan, M.; Ma, L.; Duan, Q.; Jiang, W. The effects of pulsed electromagnetic fields combined with a static magnetic intramedullary implant on the repair of bone defects: A preliminary study. Electromagn. Biol. Med. 2019, 38, 210-217. [CrossRef]

25. Parate, D.; Franco-Obregón, A.; Fröhlich, J.; Beyer, C.; Abbas, A.A.; Kamarul, T.; Hui, J.H.; Yang, Z. Enhancement of mesenchymal stem cell chondrogenesis with short-term low intensity pulsed electromagnetic fields. Sci. Rep. 2017, 7, 9421. [CrossRef] [PubMed]

26. Andrew, C.; Bassett, L.; Pawluk, R.J.; Pilla, A.A. Augmentation of bone repair by inductively coupled electromagnetic fields Science 1974, 184, 575-577. [CrossRef] [PubMed]

27. Martino, C.F.; Belchenko, D.; Ferguson, V.; Nielsen-Preiss, S.; Qi, H.J. The effects of pulsed electromagnetic fields on the cellular activity of SaOS-2 cells. Eur. Bioelectromagn. Assoc. 2008, 29, 125-132. [CrossRef] [PubMed]

28. Tong, J.; Sun, L.; Zhu, B.; Fan, Y.; Ma, X.; Yu, L.; Zhang, J. Pulsed electromagnetic fields promote the proliferation and differentiation of osteoblasts by reinforcing intracellular calcium transients. Bioelectromagnetics 2017, 38, 541-549. [CrossRef] [PubMed]

29. Kim, M.-O.; Jung, H.; Kim, S.-C.; Park, J.-K.; Seo, Y.-K. Electromagnetic fields and nanomagnetic particles increase the osteogenic differentiation of human bone marrow-derived mesenchymal stem cells. Int. J. Mol. Med. 2015, 35, 153-160. [CrossRef] [PubMed]

30. Jazayeri, M.; Shokrgozar, M.A.; Haghighipour, N.; Bolouri, B.; Mirahmadi, F.; Farokhi, M.J.C.J. Effects of electromagnetic stimulation on gene expression of mesenchymal stem cells and repair of bone lesions. Cell J. 2017, 19, 34.

31. Lim, K.; Hexiu, J.; Kim, J.; Seonwoo, H.; Cho, W.J.; Choung, P.-H.; Chung, J.H.J.B.r.i. Effects of electromagnetic fields on osteogenesis of human alveolar bone-derived mesenchymal stem cells. BioMed Res. Int. 2013, 2013, 296019. [CrossRef]

32. Chang, W.H.S.; Chen, L.T.; Sun, J.S.; Lin, F.H. Effect of pulse-burst electromagnetic field stimulation on osteoblast cell activities. Eur. Bioelectromagn. Assoc. 2004, 25, 457-465. [CrossRef]

33. Hyun, S.-Y.; Lee, J.-H.; Kang, K.-J.; Jang, Y.-J.J.M. Effect of FGF-2, TGF- $\beta-1$, and BMPs on teno/ligamentogenesis and osteo/cementogenesis of human periodontal ligament stem cells. Mol. Cells 2017, 40, 550. [CrossRef]

34. Kwon, S.J.; Kim, Y.M.; Jang, H.J.; Seo, Y.K. Synergistic effect of rice bran extract and extremely low-frequency electromagnetic fields on dermal papilla/melanocytes in melanogenesis. Bioelectromagnetics 2018, 39, 595-603. [CrossRef]

35. Song, M.; Lee, J.-H.; Bae, J.; Bu, Y.; Kim, E.-C. Human dental pulp stem cells are more effective than human bone marrow-derived mesenchymal stem cells in cerebral ischemic injury. Cell Transplant. 2017, 26, 1001-1016. [CrossRef]

36. Ledesma-Martínez, E.; Mendoza-Núñez, V.M.; Santiago-Osorio, E. Mesenchymal stem cells derived from dental pulp: A review. Stem Cells Int. 2016, 2016, 4709572. [CrossRef] [PubMed]

37. Costantini, E.; Sinjari, B.; D'Angelo, C.; Murmura, G.; Reale, M.; Caputi, S. Human Gingival Fibroblasts Exposed to Extremely Low-Frequency Electromagnetic Fields: In Vitro Model of Wound-Healing Improvement. Int. J. Mol. Sci. 2019, 20, 2108. [CrossRef]

38. Yin, Y.; Chen, P.; Yu, Q.; Peng, Y.; Zhu, Z.; Tian, J. The effects of a pulsed electromagnetic field on the proliferation and osteogenic differentiation of human adipose-derived stem cells. Med. Sci. Monit. Int. Med. J. Exp. Clin. Res. 2018, 24, 3274. [CrossRef]

39. Leone, L.; Podda, M.V.; Grassi, C. Impact of electromagnetic fields on stem cells: Common mechanisms at the crossroad between adult neurogenesis and osteogenesis. Front. Cell. Neurosci. 2015, 9, 228. [CrossRef] [PubMed] 
40. Ehnert, S.; Schröter, S.; Aspera-Werz, R.H.; Eisler, W.; Falldorf, K.; Ronniger, M.; Nussler, A.K. Translational Insights into Extremely Low Frequency Pulsed Electromagnetic Fields (ELF-PEMFs) for Bone Regeneration after Trauma and Orthopedic Surgery. J. Clin. Med. 2019, 8, 2028. [CrossRef] [PubMed]

41. Santini, S.J.; Cordone, V.; Falone, S.; Mijit, M.; Tatone, C.; Amicarelli, F.; Di Emidio, G.J. Role of mitochondria in the oxidative stress induced by electromagnetic fields: Focus on reproductive systems. Oxidative Med. Cell. Longev. 2018, 2018, 5076271. [CrossRef]

42. Khaki, A.A.; Khaki, A.; Gharachour, L.S.; Khourshidi, F.; Taj, A.N.; Madinei, N. Pre and post natal exposure of 50 Hz electromagnetic fields on prostate glands of rats: An electron microscopy study. Iran. J. Reprod. Med. 2008, 6, 77-82.

43. Korpinar, M.; Kalkan, M.; Tuncel, H.J.B.L.L. The $50 \mathrm{~Hz}(10 \mathrm{mT})$ sinusoidal magnetic field: Effects on stress-related behavior of rats. Bratisl. Lek. List. 2012, 113, 521-524. [CrossRef] [PubMed]

44. Schwartz, Z.; Simon, B.; Duran, M.; Barabino, G.; Chaudhri, R.; Boyan, B.J. Pulsed electromagnetic fields enhance BMP-2 dependent osteoblastic differentiation of human mesenchymal stem cells. J. Orthop. Res. 2008, 26, 1250-1255. [CrossRef]

45. Ross, C.L.; Siriwardane, M.; Almeida-Porada, G.; Porada, C.D.; Brink, P.; Christ, G.J.; Harrison, B.S. The effect of low-frequency electromagnetic field on human bone marrow stem/progenitor cell differentiation. Stem Cell Res. 2015, 15, 96-108. [CrossRef] [PubMed]

46. Kang, K.-J.; Ryu, C.-J.; Jang, Y.-J. Identification of dentinogenic cell-specific surface antigens in odontoblast-like cells derived from adult dental pulp. Stem Cell Res. Ther. 2019, 10, 128. [CrossRef] [PubMed]

47. Matsui, M.; Kobayashi, T.; Tsutsui, T.W. CD146 positive human dental pulp stem cells promote regeneration of dentin/pulp-like structures. Hum. Cell 2018, 31, 127-138. [CrossRef]

48. Noda, S.; Kawashima, N.; Yamamoto, M.; Hashimoto, K.; Nara, K.; Sekiya, I.; Okiji, T. Effect of cell culture density on dental pulp-derived mesenchymal stem cells with reference to osteogenic differentiation. Sci. Rep. 2019, 9, 5430. [CrossRef]

49. Potdar, P.D.; Jethmalani, Y.D. Human dental pulp stem cells: Applications in future regenerative medicine. World J. Stem Cells 2015, 7, 839. [CrossRef]

50. Semeghini, M.S.; Fernandes, R.R.; Chimello, D.T.; Oliveira, F.S.d.; Bombonato-Prado, K.F. In vitro evaluation of the odontogenic potential of mouse undifferentiated pulp cells. Braz. Dent. J. 2012, 23, 328-336. [CrossRef]

51. Hanawa, M.; Takano, Y.; Wakita, M. An autoradiographic study of calcium movement in the enamel organ of rat molar tooth germs. Arch. Oral Biol. 1990, 35, 899-906. [CrossRef]

52. Yu, D.; Zhao, X.; Cheng, J.Z.; Wang, D.; Zhang, H.H.; Han, G.H. Downregulated microRNA-488 enhances odontoblast differentiation of human dental pulp stem cells via activation of the p38 MAPK signaling pathway. J. Cell. Physiol. 2019, 234, 1442-1451. [CrossRef]

53. Han, N.; Zheng, Y.; Li, R.; Li, X.; Zhou, M.; Niu, Y.; Zhang, Q. $\beta$-catenin enhances odontoblastic differentiation of dental pulp cells through activation of Runx2. PLoS ONE 2014, 9, e88890. [CrossRef] [PubMed]

54. Cui, D.; Xiao, J.; Zhou, Y.; Zhou, X.; Liu, Y.; Peng, Y.; Yu, Y.; Li, H.; Zhou, X.; Yuan, Q. Epiregulin enhances odontoblastic differentiation of dental pulp stem cells via activating MAPK signalling pathway. Cell Prolif. 2019, 52, e12680. [CrossRef] [PubMed]

55. Ajay Sharma, L.; Ali, M.; Love, R.; Wilson, M.; Dias, G. Novel keratin preparation supports growth and differentiation of odontoblast-like cells. Int. Endod. J. 2016, 49, 471-482. [CrossRef]

56. Umemura, N.; Ohkoshi, E.; Tajima, M.; Kikuchi, H.; Katayama, T.; Sakagami, H. Hyaluronan induces odontoblastic differentiation of dental pulp stem cells via CD44. Stem Cell Res. Ther. 2016, 7, 135. [CrossRef]

57. Ahn, J.H.; Kim, I.-R.; Kim, Y.; Kim, D.-H.; Park, S.-B.; Park, B.-S.; Bae, M.-K.; Kim, Y.-I. The Effect of Mesoporous Bioactive Glass Nanoparticles/Graphene Oxide Composites on the Differentiation and Mineralization of Human Dental Pulp Stem Cells. Nanomaterials 2020, 10, 620. [CrossRef]

58. Li, S.; Hu, J.; Zhang, G.; Qi, W.; Zhang, P.; Li, P.; Zeng, Y.; Zhao, W.; Tan, Y. Extracellular Ca ${ }^{2+}$ promotes odontoblastic differentiation of dental pulp stem cells via BMP2-mediated Smad1/5/8 and Erk1/2 pathways. J. Cell. Physiol. 2015, 230, 2164-2173. [CrossRef]

59. Saito, T.; Ogawa, M.; Hata, Y.; Bessho, K. Acceleration effect of human recombinant bone morphogenetic protein-2 on differentiation of human pulp cells into odontoblasts. J. Endod. 2004, 30, 205-208. [CrossRef]

60. Yang, W.; Harris, M.; Cui, Y.; Mishina, Y.; Harris, S.E.; Gluhak-Heinrich, J. Bmp2 is required for odontoblast differentiation and pulp vasculogenesis. J. Dent. Res. 2012, 91, 58-64. [CrossRef]

61. Lin, W.; Gao, L.; Jiang, W.; Niu, C.; Yuan, K.; Hu, X.; Ma, R.; Huang, Z. The role of osteomodulin on osteo/odontogenic differentiation in human dental pulp stem cells. BMC Oral Health 2019, 19, 22. [CrossRef]

62. Duan, P.; Bonewald, L. The role of the wnt/ $\beta$-catenin signaling pathway in formation and maintenance of bone and teeth. Int. J. Biochem. Cell Biol. 2016, 77, 23-29. [CrossRef] [PubMed]

63. Kim, Y.-M.; Kwon, S.-J.; Jang, H.-j.; Seo, Y.-K. Rice bran mineral extract increases the expression of anagen-related molecules in human dermal papilla through wnt/catenin pathway. Food Nutr. Res. 2017, 61, 1412792. [CrossRef]

64. Da Rosa, W.; Piva, E.; da Silva, A. Disclosing the physiology of pulp tissue for vital pulp therapy. Int. Endod. J. 2018, 51, 829-846. [CrossRef]

65. Amirhosseini, M.; Madsen, R.V.; Escott, K.J.; Bostrom, M.P.; Ross, F.P.; Fahlgren, A. GSK-3 $\beta$ inhibition suppresses instabilityinduced osteolysis by a dual action on osteoblast and osteoclast differentiation. J. Cell. Physiol. 2018, 233, 2398-2408. [CrossRef] [PubMed] 
66. Moon, R.T.; Bowerman, B.; Boutros, M.; Perrimon, N. The promise and perils of Wnt signaling through $\beta$-catenin. Science 2002, 296, 1644-1646. [CrossRef] [PubMed]

67. Yang, J.; Ye, L.; Hui, T.-Q.; Yang, D.-M.; Huang, D.-M.; Zhou, X.-D.; Mao, J.J.; Wang, C.-L. Bone morphogenetic protein 2-induced human dental pulp cell differentiation involves p38 mitogen-activated protein kinase-activated canonical WNT pathway. Int. J. Oral Sci. 2015, 7, 95-102. [CrossRef] [PubMed]

68. Chen, L.; Song, Z.; Huang, S.; Wang, R.; Qin, W.; Guo, J.; Lin, Z. lncRNA DANCR suppresses odontoblast-like differentiation of human dental pulp cells by inhibiting wnt/ $\beta$-catenin pathway. Cell Tissue Res. 2016, 364, 309-318. [CrossRef]

69. Rodríguez-Carballo, E.; Gámez, B.; Ventura, F. p38 MAPK signaling in osteoblast differentiation. Front. Cell Dev. Biol. 2016, 4, 40. [CrossRef]

70. Yun, H.-M.; Kang, S.-K.; Singh, R.K.; Lee, J.-H.; Lee, H.-H.; Park, K.-R.; Yi, J.-K.; Lee, D.-W.; Kim, H.-W.; Kim, E.-C. Magnetic nanofiber scaffold-induced stimulation of odontogenesis and pro-angiogenesis of human dental pulp cells through Wnt/MAPK/NF-kB pathways. Dent. Mater. 2016, 32, 1301-1311. [CrossRef] 